\title{
Exclusive breastfeeding and professionals from the family health strategy
}

\author{
Aleitamento materno exclusivo e os profissionais da estratégia saúde da família \\ Lactancia materna exclusiva y los profesionales de la estrategia de salud familiar
}

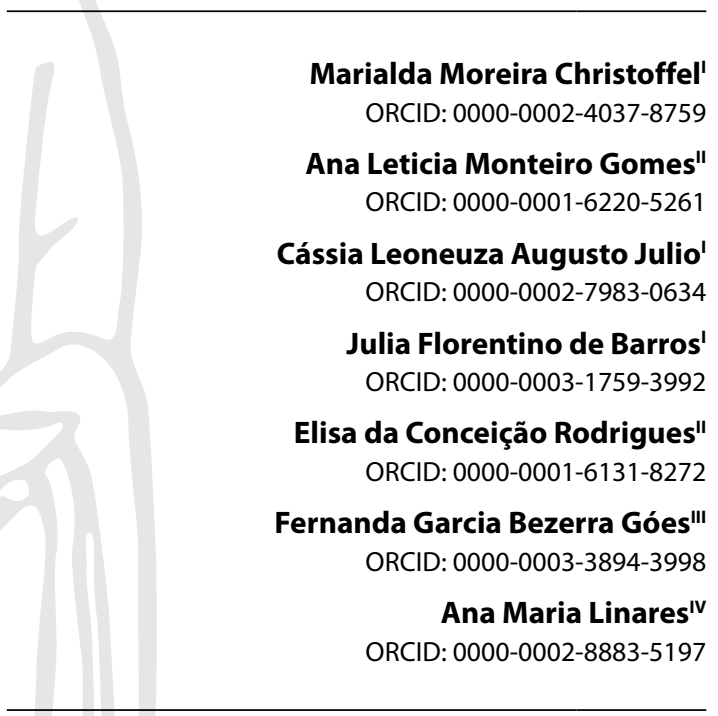

'Universidade Federal do Rio de Janeiro. Macaé, Rio de Janeiro, Brazil.

"Universidade Federal do Rio de Janeiro. Rio de Janeiro, Rio de Janeiro, Brazil. "'Universidade Federal Fluminense, Instituto de Humanidades e Saúde. Rio das Ostras, Rio de Janeiro, Brazil. "Vollege of Nursing, University of Kentucky. Lexington, Kentucky, United States of America.

How to cite this article: Christoffel MM, Gomes ALM, Julio CLA, Barros JF, Rodrigues EC, Goés FGB, et al. Exclusive breastfeeding and professionals from the family health strategy.

Rev Bras Enferm. 2022;75(3):e20200545. https://doi.org/10.1590/0034-7167-2020-0545

Corresponding author:

Ana Leticia Monteiro Gomes E-mail: analeticia.eean.ufrj@gmail.com

EDITOR IN CHIEF: Antonio José de Almeida Filho ASSOCIATE EDITOR: Elucir Gir

\section{ABSTRACT}

Objectives: to analyze the perception of health professionals about exclusive breastfeeding in Family Health Strategy units in the city of Macaé. Methods: qualitative study carried out in four units of the Family Health Strategy in the city of Macaé, Rio de Janeiro. Thirty health professionals were interviewed from March to May 2019. Textual contents were processed in the IRaMuTeQ ${ }^{*}$ software by the Descending Hierarchical Classification. Results: professionals use different strategies for actions to promote, protect and support breastfeeding in prenatal consultations, but social and cultural determinants are important issues that interfere in this process, the involvement of the family being essential for the success of this practice. Final Considerations: health professionals, including nurses, need training and qualification to strengthen the support and social network of pregnant women and insert the family in the different strategies used to improve adherence to exclusive breastfeeding.

Descriptors: Breast Feeding; Health Personnel; Family Health Strategy; Primary Health Care; Public Health Nursing.

\section{RESUMO}

Objetivos: analisar a percepção dos profissionais de saúde sobre aleitamento materno exclusivo em unidades de Estratégia Saúde da Família do município de Macaé. Métodos: estudo qualitativo realizado em quatro unidades de Estratégia Saúde da Família no município de Macaé, estado do Rio de Janeiro. Entrevistaram-se 30 profissionais de saúde entre março e maio de 2019. Os conteúdos textuais foram processados no software IRaMuTeQ pela Classificação Hierárquica Descendente. Resultados: os profissionais utilizam diferentes estratégias para ações de promoção, proteção e apoio ao aleitamento materno nas consultas de pré-natal, mas determinantes sociais e culturais são questões importantes que interferem nesse processo, sendo essencial o envolvimento da família para o sucesso dessa prática. Considerações Finais: os profissionais de saúde, incluindo os enfermeiros, necessitam de treinamento e capacitação para fortalecer o apoio e a rede social da gestante e inserir a família nas diferentes estratégias utilizadas para melhorar a adesão ao aleitamento materno exclusivo. Descritores: Aleitamento Materno; Pessoal de Saúde; Estratégia Saúde da Família; Atenção Primária à Saúde; Enfermagem em Saúde Pública.

\section{RESUMEN}

Objetivos: analizar la percepción de los profesionales de la salud sobre la lactancia materna exclusiva en las unidades de la Estrategia Salud de la Familia de la ciudad de Macaé. Métodos: estudio cualitativo realizado en cuatro unidades de la Estrategia Salud de la Familia en la ciudad de Macaé, Rio de Janeiro. Treinta profesionales de la salud fueron entrevistados de marzo a mayo de 2019. Los contenidos textuales fueron procesados en el software IRaMuTeQ por la Clasificación Jerárquica Descendente. Resultados: los profesionales utilizan diferentes estrategias de acciones para promover, proteger y apoyar la lactancia materna en las consultas prenatales, pero los determinantes sociales y culturales son cuestiones importantes que interfieren en este proceso, siendo el involucramiento de la familia fundamental para el éxito de esta práctica. Consideraciones Finales: los profesionales de la salud, incluidos los enfermeros, necesitan capacitación y capacitación para fortalecer el apoyo y la red social de la gestante e insertar a la familia en las diferentes estrategias utilizadas para mejorar la adherencia a la lactancia materna exclusiva.

Descriptores: Lactancia Materna; Personal de Salud; Estrategia de Salud Familiar; Atención Primaria de Salud; Enfermería en Salud Pública. 


\section{INTRODUCTION}

In the last 40 years, a whole set of public health policies aimed at promoting, protecting, and supporting breastfeeding has been implemented worldwide and nationally. In Brazil, significant improvements in breastfeeding (BF) have been evidenced in the last three decades ${ }^{(1-2)}$.

In 2019, the prevalence of exclusive breastfeeding (EBF) among children under four months was $60 \%$ in the country, with the highest percentage in the Southeast Region (63.5\%) and lowest in the Northeast (55.8\%). However, the rate drops to $45 \%$ in babies up to six months, the age recommended for EBF by the World Health Organization (WHO). Comparing the data from the Estudo Nacional de Alimentação e Nutrição Infantil (National Study of Infant Food and Nutrition) (ENANI) with other nationally representative surveys aimed at evaluating children under five years old (1986, 1996, and 2006) enables the assessment of the evolution of these indicators over 34 years in Brazil, with a knowledge gap of 14 years (between 2006 and 2020) ${ }^{(3)}$.

Many factors are still determining for early weaning, such as maternal socioeconomic and cultural conditions, low maternal education, maternal smoking, cesarean delivery, separation of the mother-baby dyad, as well as assistance factors, namely, lack of orientation on breastfeeding for mothers and fathers during prenatal care, along with the lack of peers and lactation support before and after birth by breastfeeding consultants ${ }^{(4-5)}$.

The multifactorial determinants of breastfeeding need supportive measures at various levels, from legal and policy guidelines to social attitudes and values, women's working and employment conditions, and health services to enable women to breastfeed. When relevant interventions are adequately delivered, breastfeeding practices are responsive and can improve rapidly ${ }^{(6-8)}$.

Studies indicate that health professionals need to be better trained and updated in breastfeeding promotion, protection, and support. For that, it requires political support and financial investment. There is a need to implement regular training programs and monitoring courses that train and update the professionals working to assist pregnant women, mothers, and children in Primary Care about breastfeeding and complementary feeding. Among health professionals' strategies stand out the Iniciativa Unidade Básica Amiga da Amamentação (Breastfeeding-Friendly Primary Care Unit Initiative) (IUBAAM), which proposes implementing the "Ten Steps for Successful Breastfeeding" in the Primary Health Care Units ${ }^{(8-10)}$.

Health professionals should recognize the importance of inserting the pregnant women support networks in prenatal care and its continuity during the puerperium. Studies must be conducted to identify the difficulties encountered by professionals to exchange knowledge about breastfeeding in the health education process ${ }^{(11)}$. Thus, local research is justified to recognize the professionals' perception on the subject. This is an essential starting point for the definition of specific actions and strategies aimed at empowering the Family Health Strategy teams for the process of protection, promotion, and support of EBF. Then, we will seek to contribute to the design of continuing education programs aligned with the needs of the team and the clientele in the region.

\section{OBJECTIVES}

To analyze the perception of health professionals about exclusive breastfeeding in Family Health Strategy units.

\section{METHODS}

\section{Ethical aspects}

The study is part of the multicenter project entitled "Sociocultural determinants of exclusive breastfeeding in Brazil". It was approved by the Research Ethics Committee of the Anna Nery School of Nursing, at the São Francisco de Assis Hospital.

\section{Type of study}

This is a qualitative, descriptive, exploratory research. The EQUATOR Network's COREQ instrument was used to guide the methodology of the study.

\section{Methodological procedures}

\section{Study setting}

The research was conducted in four Family Health Strategy (FHS) units in Macaé, State of Rio de Janeiro (RJ), Brazil. The selected units were chosen based on the maternal and child epidemiological profile, regional peculiarities, interest of municipal policymakers, interaction between the university and health services.

Macaé is the 13th most populous municipality in Rio de Janeiro, classified as medium-sized, and divided into six districts: Sede, Cachoeiros de Macaé, Córrego do Ouro, Glicério, Frade, and Sana. According to the Brazilian Institute of Geography and Statistics (IBGE), its population in the last Census of 2010 was 206,728 people, with an estimated 261,501 people in 2020 . The Municipal Human Development Index is 0.764 , with an infant mortality rate of 11.97 deaths per thousand live births. The rate of hospitalizations caused by diarrhea is 0.2 per thousand inhabitants. According to information from the Brazilian Institute of Geography and Statistics (IBGE), the population is predominantly urban, with 202,859 respective households and 3,869 rural households ${ }^{(12)}$.

The city has 32 Family Health Strategy centers and three Basic Health Units that provide habitual/low-risk prenatal consultations. It also has the Núcleo de Atenção à Mulher e à Criança (NUAMC) (Center for the Care of Women and Children), a reference in prenatal care for high-risk pregnancies; and two units for teenage prenatal care (high risk), the so-called Centros de Referência ao Adolescente (Adolescent Reference Centers) (CRA).

It has also available the Casa da Criança e do Adolescente for teenagers (Children's and Adolescents'Home), where professionals provide guidance to families and reinforce the importance of breastfeeding. In this unit, the Breastfeeding Clinic has a multidisciplinary staff from different areas of health (speech therapy, pediatrics, psychology, social work, nutrition, and pediatric dentistry). The service has existed since 2017 and 
arose from the need to guide and monitor puerperal women, aiming at EBF. Babies with alterations in the Neonatal Tongue Screening Test are referred to the pediatric dentist. In addition, the team provides care to instruct breastfeeding students and workers about milking and storage of breast milk to continue breastfeeding when they return to their activities.

\section{Data source}

We included all health professionals who had worked in the units for at least one year, who provided care to pregnant women and women in the puerperium and/or consultations for monitoring child growth and development. The study excluded health professionals who were on vacation or sick leave during the data collection period.

To ensure confidentiality and anonymity and to preserve the participants' identity, they were designated by letters and numbers according to their professional category and interview order: community health agents (CHA 1), nursing technicians (NUR-TEC 3), nurses (NUR 6), physicians (MED 29), and dentists (DENT 30).

\section{Collection and organization of data}

Data were collected between March 2019 and May 2019, during daytime hours.

Interviews were conducted with a semi-structured script, guided by the following questions: "Based on your experience: What strategies do you suggest to promote exclusive breastfeeding in your community? What is your role in promoting breastfeeding? Tell me about beliefs and cultural factors that influence the choice of infant feeding? Do you believe that women in your community face any barriers that prevent exclusive breastfeeding? What are they? What kind of support do women receive during breastfeeding in your community?".

At first, the unit coordinators were contacted to better understand the dynamics of each unit regarding the care and schedules of health professionals before conducting the interviews in the units. Then, the interview was scheduled with the professionals according to their availability and carried out in a reserved environment after customer service hours.

After the interview, the participants were asked if they were willing to remain in the research or change their answers; nobody canceled the participation. The interviews, with an average duration of 20 minutes, were recorded on digital media and, as soon as they ended, they were immediately transcribed in full.

The interviews of all health professionals were saved in a single file in "utf8" format. Each professional had their interview separated by a command line considering the variables: professional category, age, gender, time in training, time working with breastfeeding, time working in Primary Care, and attendance of course on breastfeeding in the last year.

After transcription, the text corpora from the interviews were proofread for spelling without altering their substance and were standardized for acronyms and word-joining according to instructions of the software IRaMuTeQ ${ }^{\circ}$ (Interface de $R$ pour les Analyses Multidimensionnelles de Textes et de Questionnaires) ${ }^{(13)}$.

\section{Data analysis}

The IRaMuTeQ ${ }^{\circ}$ program offers five types of processing. However, this study used the Descending Hierarchical Classification (DHA), with an option for simple text segments recommended for short answers and classified according to their respective higher frequency vocabularies and higher chi-square values in a given class. Therefore, three steps concerning this analysis method were followed: preparation and coding of the initial text, the DHA, and the interpretation of the classes ${ }^{(13)}$.

Performing the hierarchical classification with the data processing generated the dendrogram of classes. Therefore, each text segment in each class was read thoroughly to understand and name each class. The responses were grouped according to the subject. Finally, the inferential interpretation was performed with consistent references to allow the interpretation of the collected data. The process of building these categories was based on the scientific literature on breastfeeding in Primary Care.

\section{RESULTS}

Thirty health professionals participated: six nurses, five nursing technicians, three physicians, fifteen community health agents, and one dental surgeon. The participants' ages ranged from 21 to 56 years old, and their professional training time ranged from 1 to 28 years. The majority $(n=16 ; 53.3 \%)$ had participated in treatment or training on the subject (breastfeeding) in the last year. The time of experience in breastfeeding varied from 1 month to 28 years.

The overall text corpus consisted of 30 texts, separated into 299 text segments (TS), with a total of 10,478 word occurrences, 1,130 distinct words, and 545 with a single occurrence (hapax). The hierarchical analysis retained 249 TS, obtaining a score of $83.28 \%$. After reducing the words to their roots, 1,130 lemmatizations were obtained, resulting in 821 analyzable active forms.

Based on the analyzed content, by the DHA method of grouping according to the occurrence of words, two sub corpus were formed, from which six classes of distinct segments were established. The first was composed of Classes 1 and 6. There was a second subdivision in the second sub corpus, comprising Classes 2 and 3; and Classes 4 and 5. The dendrogram in Figure 1 summarizes the classes, the words that compose them, and the percentage value with the total of the corpus analyzed about the perception of health professionals on breastfeeding.

The classes were carefully analyzed for the denomination of each one of them and arranged in two thematic axes based on the subdivisions derived from the analytical process of the IRaMuTeQ. Consequently, Axis 1 was designated "Promotion and support of breastfeeding perceived by health professionals" and was composed of the following classes: 1 - Health professionals' strategies to guide and support mothers on breastfeeding; Class 6 - Promotion and support strategies: support group, family support, home visits, and professional training. Axis 2 was designated as "Hindering factors perceived by health professionals for not exclusively breastfeeding," and its classes were: 2 - Myths and beliefs that influence weaning; 3 - Maternal stress influencing breastfeeding; 4 - Family influence on breastfeeding; 5 - The influence of returning to work on weaning. 


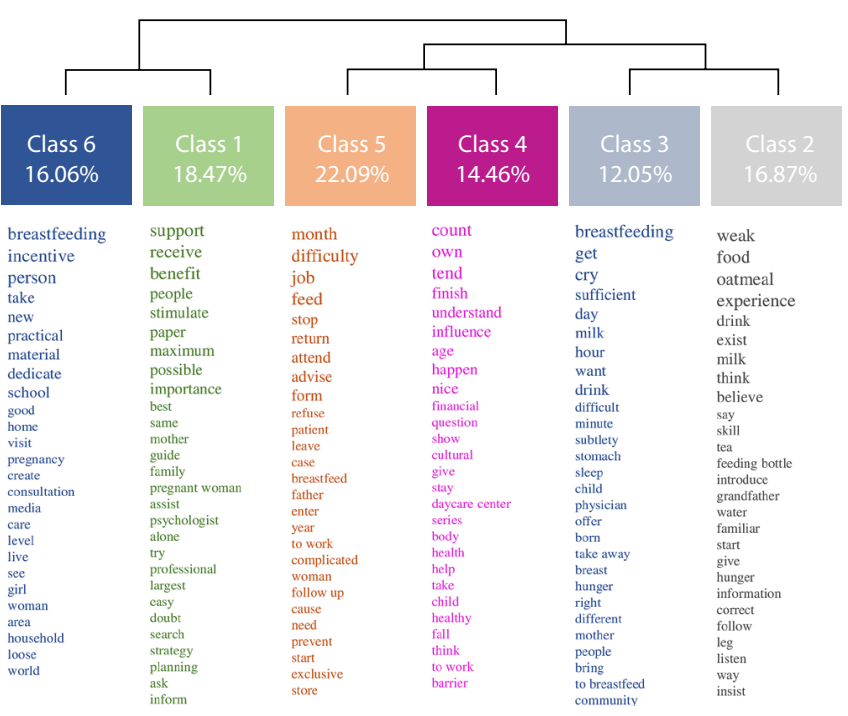

Figure 1 - Dendrogram of the Descending Hierarchical Classification with the partitions and lexicons of the research corpus, Rio de Janeiro, Rio de Janeiro, Brazil, 2019

\section{Axis 1 - The promotion and support of breastfeeding perceived by health professionals}

\section{Class 1 - Health professionals' strategies to guide and sup- port mothers about breastfeeding}

This class includes $46 \mathrm{TS}$, representing $18.47 \%$ of the material classified for analysis. This class is associated with the following variables: Health professionals with 50 to 56 years old (chi2 -6.69), time of professional training from 5 to 10 years (chi2 - 5.97), medical professional category (chi2 - 5.13), and time working in Primary Care over ten years (chi2 - 2.95). The outstanding participant in this class was respondent MED 1 (chi2 -14.4). The words with $p$ $<0.0001$ were: support, receive and benefit.

[...] We do the support work with pregnant women, the puerperium visits and the consultations, then childcare consultations [puericulture] [...] we keep working. I don't know, the milk bank would be a good strategy, but at the macro level. (NUR 29)

[...] we give all the support possible for the child and the mother. The help of the professionals, the community agent, every 15 days to check how she is doing. And here, at the health center, we follow up on the child's progress. (CHA 6)

[...] The role is mainly in the sense of orientation, about the importance of breastfeeding and trying, in the best way possible to stimulate that mother, orienting about the benefits, encouraging that mother as much as I can. (MED 1)

[...] I believe the mother only receives support from our professionals. I guess a lot of talking about the importance of breastfeeding, watching some videos, organizing groups for pregnant women. I think are very important to understand the importance of breastfeeding. (NUR-TEC 3)
Class 6 - Promotion and support strategies: support group, family support, home visits and professional training

In this class, there are $40 \mathrm{TS}$, representing $16.06 \%$ of the material classified for analysis. The class is associated with the following variables: professional category nurse (chi2 -11.84), health professionals with age between 35 and 42 years old (chi2 - 11.11), professional training time of more than ten years (chi2 -3.88), and time working with breastfeeding - from 5 to 10 years (chi2 - 9.87). The prominent participants in this class were respondents NUR 5 (chi2 -22.44) and CHA 6 (chi2 -21.40). The words with $p<0.0001$ were: breastfeeding, encourage, person, take, new, practical, material, dedicate, school, and good.

[...] The family has to be the primary support. We are not with the woman all the time, so if the family does not support it from the partner and the child's grandparents [...] they must support breastfeeding. The theory is lovely, it's easy to talk about the benefits of breastfeeding, but the practice is different; it's not so easy, so she will need the support of everyone. (NUR 2)

[...] Women who have their mothers nearby encourage breastfeeding. There is a girl in my area who had a mother-in-law who encouraged her breastfeeding. When there are close relatives, there is always encouragement. (CHA 3)

[...] We have the breastfeeding project that includes the postpartum visit, and then we promote meetings with women to talk about breastfeeding, to make them strengthen each other. (CHA 6)

[...] So, we created an intervention project that even has a banner. We carried out theoretical and practical training, taking videos and material. In 2017, we decided to train all the community agents from all the Family Health Teams. Everyone was imbued in this work. (NUR 5)

\section{Axis 2 - Hindering factors perceived by health profession- als for not exclusively breastfeeding}

\section{Class 2 - Myths and beliefs that influence weaning}

This class has 42 TS, representing $16.87 \%$ of the material classified for analysis. The class has an association with the following variables: professional category nursing technician (chi2 - 6.13), health professionals who have not taken a course on breastfeeding in the last year (chi2 - 4.24), and time working with breastfeeding - from 0 to 5 years incomplete (chi2 - 4.0). The prominent participants in this class were NUR-TEC 5 (chi2 - 4.54) and CHA 4 (chi2 - 6.71) respondents. The words with $p<0.0001$ were: weak, food, oatmeal, experience, baby, exist, milk, thing, belief, and say.

[...] There is a lot of myth that the baby, especially when the baby is a boy, overeats, feels very hungry, my milk is weak, I fail to produce enough milk. (CHA 6)

[...] Some types of religion, for example, are not very favorable of breastfeeding and encourage the baby to eat earlier. The culture passed from mother to daughter says there is the placement of weak milk, that milk has no water, the child must drink water and tea. (NUR 26) 
[...] And another thing they say is that the baby sucks a lot; the breast milk doesn't sustain the baby. I must give the bottle because the breast milk doesn't support the baby, and the belly is empty. (NUR-TEC 5)

[...] the baby needs the pacifier to calm down; the baby should be nurtured every three hours; you can give tea, water, oatmeal. (DENT 1)

\section{Class 3 - Maternal stress influencing breastfeeding}

This class contains $30 \mathrm{TS}$, representing $12.05 \%$ of the material classified for analysis. It is evident that this class is associated with the following variables: health professional with 21 to 27 years old (chi2 -11.36), professional category community health agent (chi2 -4.24), professional training time from 0 to 5 years (chi2 -3.76), time working with breastfeeding - from 0 to 5 years incomplete (chi2 -2.7), and professional training time (chi2 -2.33). The prominent participants in this class were respondents $\mathrm{CHA}$ 9 (chi2 -16.22), CHA 11 (chi2 -3.76) and CHA 7 (chi2 - 2.63). The words with $p<0.0001$ were: breastfeed, get, cry, enough, and day.

[...] The little girl was so hungry, irritable. The mother's breasts were so filled [with milk] that when she tried to feed the baby, and the child sucked her breast, there was a lot of milk, and the baby couldn't feed because she choked. The mother cried because the baby couldn't suckle; she was very irritated and cried a lot. (CHA 9)

[...] As breast milk is light and the child ends up sucking more, they wake up more at night to breastfeed, so many end up not adhering entirely to breast milk. I think that the mother-in-law interferes a lot in the way mothers accept breastfeeding, so they end up going for the easiest way. (CHA 11)

[...] In my area, there was a mother that I accompanied. The child really couldn't breastfeed: out of the blue, she couldn't breastfeed anymore. The milk dried up, the mother cried a lot; it just dried up; after a while, she learned that she could take medication. (CHA 7)

[...] Many mothers say that they can't breastfeed because the baby doesn't gain weight. They end up worried and get stressed. In fact, breast milk ends up not being enough. The production ends up decreasing, so they abandon it earlier. (MED 2)

\section{Class 4 - Family influence on breastfeeding}

This class has $36 \mathrm{TS}$, representing $14.46 \%$ of the material classified for analysis. This class had no association with any variable, and the words with $p<0.0001$ were: count, own, tend, finish, understand, influence, and age.

[...] So they listen a lot to women who have already been mothers, and most of them are taken care of by their grandmothers, so they are the ones who introduce them and that's it, it's cultural. (CHA 2)

[...] Even if we guide, the cultural influence has its space because the mother in this period is very fragile and tends to really listen and gives in to that influence. (NUR 4)

[...] I accompany some families, where the family members give a lot of hunches, it's really complicated, because it's a mother or mother-in-law who invokes and says that the child is not feeding properly, that the milk is weak. Then they start wanting to insert food, some go for the family, others respect the time of exclusive breastfeeding, and we explain the reason. (CHA 8)

\section{Class 5 - The influence of returning to work on weaning}

This class has 55 TS, representing $22.09 \%$ of the material classified for analysis. The class was associated with the following variables:Time working in Primary Care -5 to 10 years (chi2 - 8.61), health professionals who have taken a course on breastfeeding in the last year (chi2 - 7.69), and time working with breastfeeding from 5 to 10 years (chi2 - 4.2). The prominent participants in this class were respondents CHA 10 (chi2 - 7.1), NUR 6 (chi2 - 4.72), NUR 1 (chi2 - 4.26), CHA 8 (chi2 - 3.74) and CHA 15 (chi2 - 3.51). The words with $p<0.0001$ were: month, difficulty, and work.

[...] Regarding work, for most women, the maternity leave lasts four months, so she has to return before the child's 6 months, which has to be exclusive breastfeeding. When I worked in another health unit, many women reported that. We oriented them to store the milk, but many reported difficulties in stocking the milk. (NUR 1)

[...] When some women return to work, they presume to stop breastfeeding, and they really stop. They already want to get some guidance on which artificial milk is best to give to their child to start getting used to it before going back to their jobs. They comment precisely that. (NUR 6)

[...] Many women end up supplementing with other milk and start introducing food before the conventional recommended date. The mothers also must go back to work and end up giving other foods [...] believing that the child will be more immune. (CHA 19)

[...] Work is a barrier because not all women have a formal job contract, and the maternity leave is also shorter, so they stop exclusive breastfeeding earlier and don't complete the six months properly. (NUR-TEC 7)

\section{DISCUSSION}

The support of health professionals since prenatal care is the initial step for the success of EBF up to 6 months. A study analyzed the presence and extent of the attributes of Primary Health Care in the breastfeeding process based on the experience of health professionals in Basic Units certified by Brazil Breastfeeding Network (Rede Amamenta Brasil), comparing it to non-certified units. The certified Units and the professionals who received the Brazil Breastfeeding Network training showed a higher degree of orientation to Primary Health Care. The data indicate that the better performance in the attributes is related, among other factors, to the better qualification of professionals to develop practices that value the promotion, protection, and support of breastfeeding, according to the principles of Primary Health Care ${ }^{(14)}$.

The support to breastfeeding, offered by health professionals during all the moments of their assistance, including home visits and conversation rounds, is primordial to increase breastfeeding period and identify early problems related to the main complications of this practice ${ }^{(15-16)}$. 
The Unit's health professionals use different strategies to promote, protect, and support breastfeeding, like orientation on the benefits of breast milk and the clinical managing of breastfeeding, home visits, groups for pregnant women, and conversation rounds. Despite all the orientations, the adherence to exclusive breastfeeding is still insufficient in the opinion of the professionals. Social and cultural factors persist among pregnant women. Although the professionals recognize the importance of the family and the support network in the breastfeeding process, their strategies to support the family in the breastfeeding process are still not part of the consultations or follow-up in home visits.

A study was developed to analyze the social networks supporting breastfeeding and implement actions to strengthen them through research-action developed in the context of the EBF in Natal. The results showed the importance of health professionals knowing the local social networks supporting BF during prenatal care to encourage and value the participation of this network in programs and actions to protect, promote and support breastfeeding, strengthening their process. The support of the nuclear family, friends, neighbors, and health professionals during the breastfeeding period is indispensable and can configure as a determining factor in breastfeeding adherence and maintenance. The educational actions carried out constituted three types of activities, which complement each other: home visits, conversation rounds, and the interaction of a virtual group ${ }^{(15)}$ - similar to the results of the present study.

Considering that many myths and beliefs hinder breastfeeding, with strong family influence (according to the findings), it is necessary to include family members in the educational practices related to the subject. Therefore, health professionals who get closer to the user and the families reinforce the social bonds, bringing out, in the exchange of experiences, the necessary strength to sustain the conscious and enlightened practice of breastfeeding in the family context ${ }^{(15)}$.

In this study, health professionals report that the woman's swollen breasts, hunger cries of the newborn, insufficient milk, and the intervention of the mother-in-law or the mother led the woman to stress, which influences whether to continue breastfeeding. These findings corroborate the evidence that the mother's psychological conditions are determinant: the stress experienced by her and reported by professionals promotes a negative effect on human physiological functions such as breastfeeding, reducing, for example, the milk ejection reflex, which reinforces the importance of professional and family support to these women ${ }^{(17)}$.

Research conducted in a city in the interior of Rio de Janeiro aimed to analyze the performance of FHS health professionals concerning breastfeeding during the puerperium detected the difficulties in the breastfeeding process reported by nursing mothers are related to lack of follow-up and cohesive information according to their needs. That can lead to inappropriate practices, such as introducing liquids and other foods before six months. That fact highlights the necessity for breastfeeding promotion, protection, and support actions by the health professionals at the Family Health Strategy ${ }^{(18)}$.

The support given by pregnant women in the opinion of health professionals comes from the experiences of other women-mothers; and grandmothers, who are references in the family for having much knowledge and culture on the practice of breastfeeding. Along these lines, an investigation to comprehend the influence of women's social networks during the breastfeeding process reinforces that planning actions aiming to promote, protect, and support breastfeeding requires understanding women's relational context, which transcends the biological aspects involved in breastfeeding process. Therefore, breastfeeding counseling is considered a valuable maternal and family support strategy ${ }^{(19-20)}$.

Counseling is a process of interaction between the health professional and pregnant and breastfeeding women and their support network and should be provided from the prenatal period up to 2 years or more. Breastfeeding counseling should promote women's self-confidence, respecting their wishes, individuality, and choices without vertically determining their actions ${ }^{(20)}$.

Breastfeeding counseling is a public health intervention considered effective to increase EBF rates and can be provided in person or remotely, prenatally and postnatally ${ }^{(21)}$. In the present study, there was an absence of counseling as a strategy to support breastfeeding, highlighting the need to update the team for this approach.

Breastfeeding counseling should be provided as a continuum of care by professionals and community health workers trained in communication skills that promote women's support and selfconfidence ${ }^{(20)}$. Therefore, professionals should not restrict their orientations to the advantages of breastfeeding but rather seek the interaction and boost of the whole women's support network.

However, there are a series of historical, socioeconomic, cultural, and individual factors that affect breastfeeding practice, like stress and maternal work, identified in this analysis. Along these lines, the literature reaffirms the unfavorable effect of work on exclusive breastfeeding of infants, which are one of the main reasons for the interruption of breastfeeding or early weaning, due to its multidimensional effect, which includes fatigue, the convenience of non-breast milk, and intensity of working hours ${ }^{(22)}$.

A study was conducted with the following objectives: to describe the profile, according to the job situation, of women with children under four months old and living in Brazilian capitals and the Federal District; and to analyze the influence of maternity leave on exclusive breastfeeding among working women. It was established that among working mothers, those on maternity leave had a lower chance of interrupting EBF in the infant's first four months of life, which reinforces the importance of extending maternity leave to six months ${ }^{(23)}$.

In Brazil, the Programa de Apoio à Mulher Trabalhadora que Amamenta (Support to Breastfeeding Working Women Program) aims to encourage policymakers of public and private companies to adhere to six-month maternity leave, with a daycare center in the workplace and a support room for breastfeeding. However, family policies still do not meet social needs, such as the extension of maternity and paternity leaves to all workers and establishing parental leave ${ }^{(24)}$.

The increase in rates and duration of EBF is a responsibility of the entire society. The social and economic impact of EBF up to the sixth month and continuing through the second year of life justifies the need for investment and intersectoral coordination to ensure this human right. The costs of non-breastfeeding are significant and should compel policymakers and donors to invest 
in expanding effective breastfeeding and nutrition interventions for infants and their mothers, thereby growing human capital development and better outcomes in the global economy. Annual economic losses due to non-breastfeeding are estimated to be between US\$ 257 billion and US\$ 341 billion, i.e., between $0.37 \%$ and $0.70 \%$ of global GDP(25).

However, although professionals can employ many strategies to support breastfeeding women labor, some limitations are imposed by the precarity of women's work, like employers' lack of commitment to breastfeeding and the invasion of the food industry by advertising milk formulas promising to imitate and replace the properties of human milk. In this sense, professionals face situational challenges in implementing policies to promote, protect, and support EBF.

\section{Study limitations}

The limitation of the study is that the research was developed with health professionals from four ESF units in the municipality of Macaé, RJ, which expresses a reality based on the subjectivity of a limited group, making it impossible to generalize the data.

\section{Contributions to the fields of Nursing, Health or Public Policy}

The findings provide subsidies for the development of policies, programs, and educational strategies, in the context of family health, based on the real needs of mothers and their families, aiming to promote contextualized guidelines that contribute to the increase of EBF rates, with consequent reduction of early weaning and infant morbidity and mortality.

\section{FINAL CONSIDERATIONS}

Health professionals use different strategies in their actions to promote, protect, and support exclusive breastfeeding, which include guidance through support groups and home visits, as well as recover the importance of family and professional training as key elements for the success of this practice. On the other hand, they point out different complicating factors, such as myths and beliefs, originated from cultural and family practices, in addition to stress and the breastfeeding woman's return to work. Consequently, there is a requirement for more investment in professionals' training regarding breastfeeding counseling practices and greater family involvement and support network in the actions. The community leaders' involvement in breastfeeding workshops can contribute to the strengthening and expansion of support groups and networks.

There is a recommendation to offer training courses on the Normas Brasileiras de Comercialização de Alimentos para Lactentes, Bicos, Chupetas e Mamadeiras (Brazilian Norms for the Commercialization of Foods for Infants, Nipples, Pacifiers, and Feeding Bottles) (NBCAL), as well as raising awareness of policymakers to implement the Iniciativa Hospital Amigo da Criança (Baby-Friendly Hospital Initiative), the Estratégias Amamenta e Alimenta Brasile Iniciativa Unidade Básica Amiga da Amamentação (Brazilian Breastfeeding and Feeding Strategies, and the Breastfeeding Friendly Basic Unit Initiative) since there are still no certified units in the region of the study.

\section{FUNDING}

This study was included in a research project funded by the National Council for Scientific and Technological Development (CNPq) with a Scientific Initiation Scholarship from the Federal University of Rio de Janeiro - Campus Macaé.

\section{ACKNOWLEDGMENT}

The authors would like to thank the Healthcare professionals of the Family Health Strategy and Roziane Azevedo Ouverney da Penha, UFRJ Nursing academic- Campus Macaé.

\section{REFERENCES}

1. Hernandez AR, Víctora CG. Biopolíticas do aleitamento materno: uma análise dos movimentos global e local e suas articulações com os discursos do desenvolvimento social. Cad Saude Publica. 2018;34(9):e00155117. https://doi.org/10.1590/0102-311X00155117

2. Boccolini CS, Boccolini PMM, Monteiro FR, Venâncio SI, Giugliani ERJ. Breastfeeding indicators trends in Brazil for three decades. Rev Saude Publica. 2017;51:108. https://doi.org/10.11606/S1518-8787.2017051000029

3. Universidade Federal do Rio de Janeiro. Estudo nacional de alimentação e nutrição infantil: ENANI-2019: resultados preliminares: indicadores de aleitamento materno no Brasil [Internet]. Rio de Janeiro: UFRJ; 2020[cited 2020 Mar 16]. Available from: https://enani. nutricao.ufrj.br/wp-content/uploads/2020/12/Relatorio-parcial-aleitamento-materno_ENANI-2019.pdf

4. Lima MML, Silva TKR, Tsupal PA, Melhem ARF, Brecailo MK, Santos EF. A influência de crenças e tabus alimentares na amamentação. Mundo Saude. 2016;40(2):221-9. https://doi.org/10.15343/0104-7809.20164002221229

5. Cohen SS, Alexander DD, Krebs NF, Young BE, Cabana MD, Erdmann P, et al. Factors associated with breastfeeding initiation and continuation: a meta-analysis. J Pediatr. 2018;203:190-6. https://doi.org/ 10.1016/j.jpeds.2018.08.008

6. Passos LP, Pinho L. Health professionals in promoting breastfeeding: integrative review. J Nurs UFPE. 2016;10(suppl 3):1507-16. https://doi. org/10.5205/1981-8963-v10i3a11092p1507-1516-2016

7. Siqueira FPC, Zutin TLM, De Macedo Kuabara CT, Martins TA. A capacitação dos profissionais de saúde que atuam na área do aleitamento materno. Investig Enferm. 2017;19(1):171-86. https://doi.org/10.11144/javeriana.ie19-1.acps

8. Rollins NC, Bhandari N, Hajeebhoy N, Horton S, Lutter CK, Martines JC, et al. Why invest, and what it will take to improve breastfeeding practices?. Lancet. 2016;387(10017):491-504. https://doi.org/10.1016/S0140-6736(15)01044-2 
9. Ramos AE, Ramos CV, Santos MM, Almeida CAPL, Martins MCC. Knowledge of healthcare professionals about breastfeeding and supplementary feeding. Rev Bras Enferm. 2018;71(6):2953-60. https://doi.org/10.1590/0034-7167-2017-0494

10. Lapa $C B$, Jacques $A D$. A promoção da saúde materna e infantil em uma unidade básica de saúde por meio da amamentação. Rev Pediatr SOPERJ [Internet]. 2016[cited 2020 Mar 16];16(1):6-10. Available from: http://revistadepediatriasoperj.org.br/numeroAtual.asp?ed=71

11. Silva DD, Schmitt IM, Costa R, Zampieri MFM, Bohn IE, Lima MM. Promotion of breastfeeding in prenatal care: the discourse of pregnant women and health professionals. REME. 2018;22:e-1103. http://www.doi.org/10.5935/1415-2762.20180031

12. Instituto Brasileiro de Geografia e Estatística (IBGE). Cidades e estados [Internet]. [Brasília, DF]: IBGE; 2020[cited 2020 Mar 16]. Available from: https://www.ibge.gov.br/cidades-e-estados/rj/macae.html

13. Souza MAR, Wall ML, Thuler ACMC, Lowen IMV, Peres AM. The use of IRaMuTeQ software for data analysis in qualitative research. Rev EsC Enferm USP. 2018;52:e03353. http://www.doi.org/10.1590/S1980-220X2017015003353

14. Melo LCO, Nakano AMS, Monteiro JCS, Furtado MCC. Primary health care attributes in breastfeeding care. Texto Contexto Enferm. 2019;28:e20170516. https://doi.org/10.1590/1980-265X-TCE-2017-0516

15. Nóbrega VCF, Melo RHV, Diniz ALTM, Vilar RLA. Social support networks for Breastfeeding: an action-research. Saude Debate. 2019;43(121):429-40. https://doi.org/10.1590/0103-1104201912111

16. McFadden A, Gavine A, Renfrew MJ, Wade A, Buchanan P, Taylor JL, et al. Support for healthy breastfeeding mothers with healthy term babies. Cochrane Database Syst Rev. 2017;28;2(2):CD001141. https://doi.org/10.1002/14651858.CD001141.pub5

17. Jalal M, Dolatian M, Mahmoodi Z, Aliyari R. The relationship between psychological factors and maternal social support to breastfeeding process. Electron Physician. 2017;9(1):3561-9. https://doi.org/10.19082/3561

18. Vargas GS, Alves VH, Rodrigues DP, Branco MBLR, Souza RMP, Guerra JVV. Atuação dos profissionais de saúde da estratégia saúde da família: promoção da prática do aleitamento materno. Rev Baiana Enferm. 2016;30(2):1-9. https://doi.org/10.18471/rbe.v30i2.14848

19. Souza MHN, Nespoli A, Zeitoune RCG. Influence of the social network on the breastfeeding process: a phenomenological study. Esc Anna Nery. 2016;20(4):e20160107. https://doi.org/10.5935/1414-8145.20160107

20. World Health Organization. Guideline: counselling of women to improve breastfeeding practices [Internet]. Geneva: WHO; 2018[cited 2020 Apr 8]. Available from: https://www.who.int/nutrition/publications/guidelines/counselling-women-improve-bf-practices/en/

21. McFadden A, Siebelt L, Marshall JL, Gavine A, Girard L-C, Symon A, et al. Counselling interventions to enable women to initiate and continue breastfeeding: a systematic review and meta-analysis. Int Breastfeed J. 2019;14:42. https://doi.org/10.1186/s13006-019-0235-8

22. Ortelan N, Venancio SI, Benicio MHA. Determinantes do aleitamento materno exclusivo em lactentes menores de seis meses nascidos com baixo peso. Cad Saude Publica. 2019;35(8):e00124618. https://doi.org/10.1590/0102-311X00124618

23. Monteiro FR, Buccini GS, Venâncio SI, Costa THM. Influência da licença-maternidade sobre a amamentação exclusiva. J. Pediatr (Rio J.). 2017;93(5):475-81. https://doi.org/10.1016/j.jped.2016.11.016

24. Kalil IR, Aguiar AC. Trabalho feminino, políticas familiares e discursos pró-aleitamento materno: avanços e desafios à equidade de gênero. Saude Debate. 2016;40(110):208-23. https://doi.org/10.1590/0103-1104201611016

25. Walters DD, Phan LTH, Mathisen R. The cost of not breastfeeding: global results from a new tool. Health Policy Plan. 2019. 2016;34(6):407-17. https://doi.org/ 10.1093/heapol/czz050 